UDC 330.15

JEL Classification: Q15, Q16, Q25, R11, R58

DOI: $10.15587 / 2706-5448.2021 .240343$

Article type «Reports on Research Projects»

\section{Hrabrin Bachev, Bozhidar Ivanov}

\title{
A STUDY ON WASTEWATER TREATMENT SLUDGE UTILIZATION IN BULGARIAN AGRICULTURE
}

The issue of sludge utilization from wastewater treatment in agriculture is an important socio-economic and environmental problem in the European Union (EU) and Bulgaria. It is becoming topical issue along with constantly growing amount of produced wastewater treatment sludge, deficiency of lands for their safe disposal, protests of population and interests' groups, tightening EU restrictions, etc. Furthermore, studies on wastewater treatment sludge utilization are multiplying in relations with their «transformation from wastes into products» and effective inclusion in supply chains and circular economy. Despite their relevance, in-depth studies of the diverse effects and critical factors of wastewater treatment sludge utilization in Bulgarian agri-food chain are at an early stage, mostly focusing on agronomic, economic and/or environmental ones. Thus, the object of research is the effective utilization of sludge from wastewater treatment in Bulgarian agriculture. In the course of the research it is used a qualitative analysis of regulations, and institutional and organizational structure, as well as surveys with managers and experts of urban wastewater treatment plants, and farmers applying and not-using sludge from wastewater treatment in their holdings. As a result of the study, the institutional, political, organizational, personal, educational, informational, social, economic, and environmental factors influencing the utilization of sludge in agriculture in two major regions of the country (Sofia and Burgas) are identified. Impact factors are generally divided into two types: factors influencing the behavior of agents, and factors determining the type and extent of the effects of sludge use in agriculture. In the future, the proposed approach has to be extended and deepen to establish the economic, sectoral and regional specificities on the basis of more representative information from all participants and interested parties in the effective utilization of wastewater treatment sludge.

Keywords: socio-economic problem, environmental problem, sludge utilization, wastewater treatment, Bulgarian agriculture, factors efficiency.

Bachev, H., Ivanov, B. (2021). A study on wastewater treatment sludge utilization in Bulgarian agriculture. Technology Audit and Production Reserves, 5 (4 (61)), 35-44. doi: http://doi.org/10.15587/2706-5448.2021.240343

\section{Introduction}

The issue of utilization of sludge from wastewater treatment is an important socio-economic and environmental problem in Bulgaria and the European [1]. The total amount of the European production of sludge is 8.7 million tonnes DS/y [2]. Its significance of the issue in Bulgaria is determined by the fact that the amount of sludge formed in the country is constantly growing, and reaches 53 thousand tons of dry matter in 2018 [3]. At the same time, according to the national goals by the end of 2020 as much as $65 \%$ of the sludge from Municipal Wastewater Treatment Plants is being recycled and materially utilized, and the remaining $35 \%$ of them is to be energetically utilized [4].

One of the main ways to utilize sludge from wastewater treatment in its use as fertilizer in agriculture [5, 6]. Sludge use in general, and in agriculture in particular, is not an automatic but a complex process that depends on many institutional, production, economic, psychological, social, environmental, etc. factors. As a result of the specific combination of the critical factors in the individual countries of the European Union, there is a great diversity in the degree of sludge use in agriculture - from almost zero in Malta, Slovenia and Slovakia to $80 \%$ in Ireland [7]. Currently, agricultural destination or use of sludge in Europe accounts for $47 \%$ of the total or $4.1 \mathrm{Mt} \mathrm{DS} / \mathrm{y}$ [2]. A recent study [8] found that a small proportion of Bulgarian farms utilize sludge on their farms.

Around the globe, there are numerous studies on the factors and efficiency of sludge use in agriculture $[5,9,10]$. Interest in this area is growing even more in connection with the new challenges related to environmental pollution, climate change, protection of human and animal health, the current COVID pandemic and others. Strict regulation and standards for sludge use have been introduced in most countries and the European Union, including in agricultural sector. Many countries (such as Germany, the Czech Republic, Hungary, France, etc.) have introduced greater restrictions 
than the EU minimum, and some countries (such as Switzerland, certain US states, etc.) have even banned the use in agriculture [7]. Recent concerns about coronavirus have led some countries (such as France) to introduce mandatory disinfection of sludge before use in agriculture [10].

In Bulgaria, regardless of their relevance, in-depth studies of the diverse effects and critical factors of sludge utilization in agriculture are a new phenomenon, single, unilateral (mainly bio-chemical and agronomic use) and at an early stage [11-13].

Therefore, to fill the existing gap, and to identify and assess the significance of the various factors affecting the effective utilization of sludge from wastewater treatment in Bulgarian agriculture is relevant. Thus, the object of research is the effective utilization of sludge from wastewater treatment in Bulgarian agriculture. The aim of research is to identify and assess the significance of the various factors influencing the effective utilization of sludge from wastewater treatment in Bulgarian agriculture.

\section{Methods of research}

Impact factors can generally be divided into two types: factors influencing (motivating and demotivating) the behavior of agents, and factors determining the type and size (formation technology) of the effects of sludge use in agriculture. If the system of incentives of the various agents involved in the process is not properly formed («managed»), the potential positive socio-economic effect of the use of sludge in agriculture will not be realized. Therefore, the specific interests and incentives of the main participants in the process (striving for maximum positive and minimum negative economic effects) should be analyzed and the extent to which the existing governance system contributes to the public interest (maximum positive and minimum negative public effects) should be assessed. In the specific conditions of each region, farm, etc. impact factors have different significance, and in many cases are interconnected or subordinate. The later requires the use of multifactorial and comparative structural analysis to correctly identify the factors and establish their significance, relationships, subordination, dynamics over time, etc.

This study is based on a qualitative analysis of the specific regulations and institutional structure related to the utilization of sludge in agriculture. It also uses the results of surveys conducted during 2020-2021 with managers and experts of Municipal Wastewater Treatment Plants (WTPs) in Sofia and Burgas region (Bulgaria), and with agricultural producers recovering and not using sludge from the two regions of the country.

Nearly half of the total amount of sludge in the country is produced in the studied two regions (Table 1).

Table 1

Amount and share of the produced sludge on the territories of Regional Environment and Waters Inspections (REWI) in Sofia and Burgas, 2018

\begin{tabular}{|c|c|c|}
\hline REWI & Amount, tons of dry sludge & Share in total, \% \\
\hline Sofia & 23101 & 43.52 \\
\hline Burgas & 3319.94 & 6.25 \\
\hline Bulgaria & 53082.62 & 100 \\
\hline
\end{tabular}

Note: built on data [3]

According to the 2018 official information in agriculture about $56 \%$ of the total sludge formed in Bulgaria is utilized [3]. In recent years, the sludge of «Sofiyska Voda»
AD (part of French company VEOLIA) has been mainly applied in agriculture, where all of the sludge formed by this treatment plant for 2018 is utilized. The Sofia region also utilizes the largest share of sludge used in the country's agriculture $-43.4 \%$ of the total. The sludge in this area has been utilized on 2169.7 ha of arable land as in 2018. A total of 38,440 tDS have been distributed, including quantities of temporarily stored sludge from 2017 [3].

\section{Research results and discussion}

3.1. Political, institutional and market factors. In order to identify and assess institutional factors, the specific institutional environment («rules of the game») and structures (agents and relationships between them) related to sludge utilization in agriculture are to be analyzed (Fig. 1). Account should also be taken of the development of important factors of the external social, market and natural environment that influence the management of the process of agricultural use of sludge - EU and state policies, the development of the research system, education, and information, evolution of markets and demand, etc. Depending on the efficiency of the management system (institutions, market, private, public and hybrid forms) there will be different degree and efficiency of sludge utilization in agriculture.

The specific institutional environment includes the various legislative and regulatory provisions and the system for their enforcements, which regulate the rights, methods, processes, and control of sludge utilization in agriculture. This analysis should also include the informal rules of the game, predetermined by the ideology of conservation farmers, interest groups and consumers, which occupy a growing place in the system of governance of society and agriculture.

One of the most important factors for the effective utilization of sludge in agriculture is the existence of modern legislation and regulations (Table 2). It is to define the rights and obligations of the various agents involved in the process (regulatory and control bodies, WTPs, farmers, etc.), standards for sludge quality and safety, soil fertility and human and animal health, norms and restrictions of application, etc. The institutional set-up also includes various state policies, programs, plans, and incentive instruments for achieving certain social goals regarding the utilization of sludge in agriculture and other sectors of production.

Well-defined «rules of the game» and adequate government intervention will create conditions for inducing effective behavior of key agents and effective (and not only) use of sludge in agriculture (maximizing the positive effects and minimizing the negative effects). Conversely, in the case of inefficient regulation (for example, complex procedures and high costs of obtaining permits for use from farms), there will be no sufficient interest in participating in the process.

In the European Union there are strict regulations for the utilization of sludge in agriculture established by the European Union Directive of 1986 [14] and other documents on the protection of the environment and human health. The EU directive encourages the use of sludge in agriculture only if it is used in areas where it does not have a negative impact on soil and agricultural products. The main requirements in the Directive are limited to compliance with limits related to the content of heavy metals and nutrients in sludge and soil, as well as limits on the annual load of agricultural land with sludge. It is also mandatory to treat the sludge before using it for fertilization. 


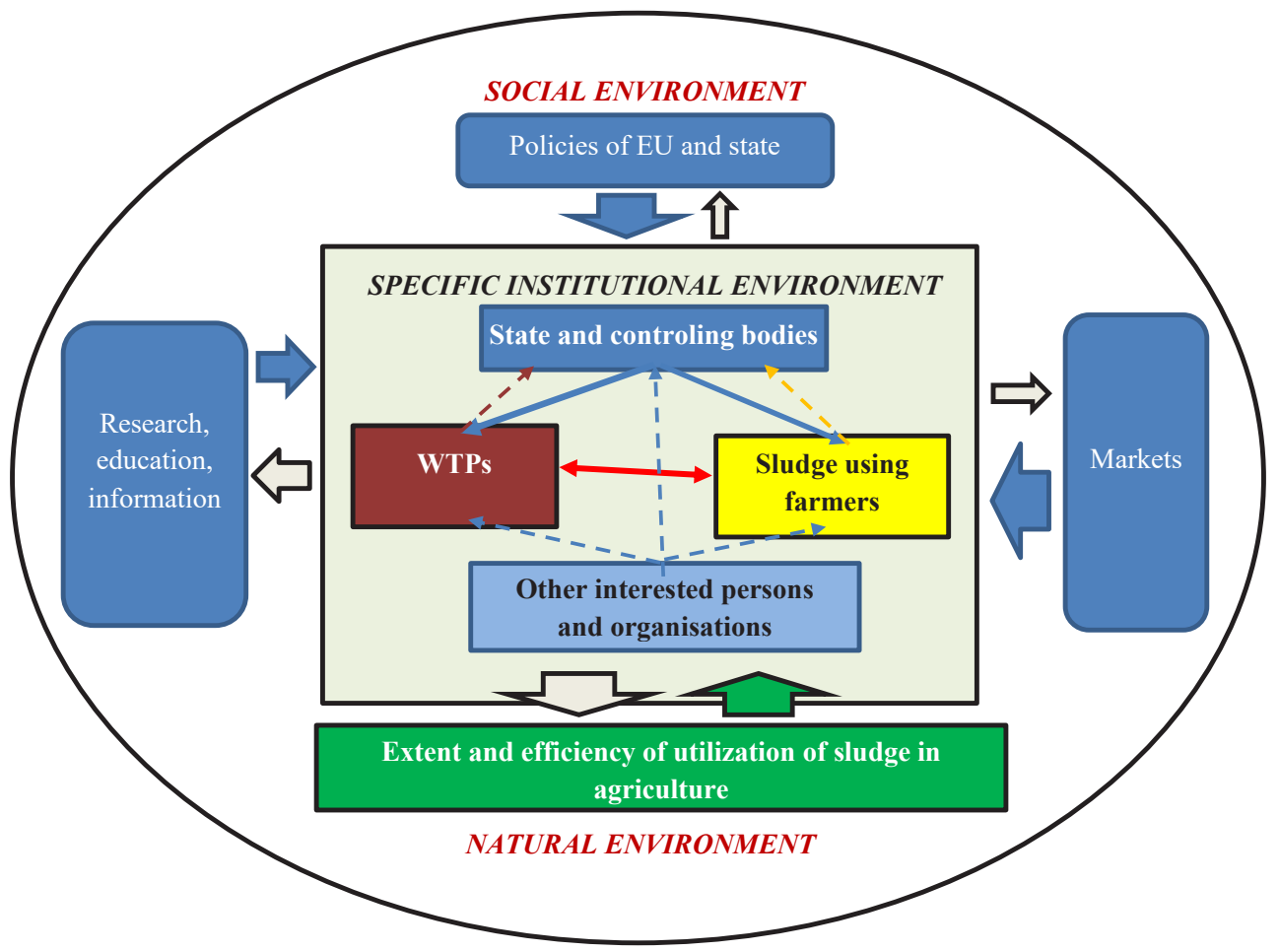

Fig. 1. Institutional environment and structure of sludge utilization in Bulgarian agriculture

Institutional, personal and educational factors for sludge utilization in Bulgarian agriculture

\begin{tabular}{|c|c|c|}
\hline Туре & Positive & Negative \\
\hline $\begin{array}{l}\text { Politically } \\
\text { and insti- } \\
\text { tutional }\end{array}$ & $\begin{array}{l}\text { 1. Long-term policy on safe sludge use in the EU. } \\
\text { 2. Modern legislation with clear procedures and standards. } \\
\text { 3. Long-term state and regional strategies. } \\
\text { 4. Restrictions on utilization on agricultural land. } \\
\text { 5. Mandatory standards for the protection of soil, water, air, biodi- } \\
\text { versity, and human and animal health }\end{array}$ & $\begin{array}{l}\text { 1. Need for a special management system. } \\
\text { 2. Long and complicated licensing procedures. } \\
\text { 3. Possibility for impunity for violation of procedures and standards. } \\
\text { 4. Possibility for development of dependency and corruption. } \\
\text { 5. Imperfect contracting (additional coordination costs, little possibility } \\
\text { for enforcement). } \\
\text { 6. Restriction of users (sole traders and legal entities). } \\
\text { 7. Restrictive goals and uncertainty related to the EU Green Deal }\end{array}$ \\
\hline $\begin{array}{l}\text { Personal } \\
\text { and orga- } \\
\text { nizational }\end{array}$ & $\begin{array}{l}\text { 1. Vision and proactive strategy of WTP. } \\
\text { 2. Logistical and material support from WTP. Innovation. } \\
\text { 3. Entrepreneurship of the farmer. } \\
\text { 4. Dualification and experience of the farmer. } \\
\text { 5. Size of the holding. } \\
\text { 6. Good and long-term relations between WTP and using farmers. } \\
\text { 7. High efficiency of self-learning and learning by doing of good managers. } \\
\text { 8. High bilateral dependency between WTP and sludge using farms }\end{array}$ & $\begin{array}{l}\text { 1. Passive strategy of WTP. } \\
\text { 2. Tendency not to take risks. } \\
\text { 3. High costs for proper treatment, storage and delivery. } \\
\text { 4. Need for precise organization and management of production. } \\
\text { 5. Difficulty to introduce in non-innovative and risk-averse farmers. } \\
\text { 6. Difficulty to introduce in cooperative farms with numerous members. } \\
\text { 7. Practice of one-year rent contract for supply of agricultural lands. } \\
\text { 8. Standard contracts for supply of sludge from WTP }\end{array}$ \\
\hline $\begin{array}{l}\text { Informa- } \\
\text { tion and } \\
\text { educational }\end{array}$ & $\begin{array}{l}\text { 1. Up-to-date, comprehensive, reliable and accessible information. } \\
\text { 2. Independent evaluations and information. «Fast» training by doing } \\
\text { of good managers. } \\
\text { 3. Provision of information and advice by the WTP. } \\
\text { 4. Close distance between user farms and WTP }\end{array}$ & $\begin{array}{l}\text { 1. Lack of sufficient scientific literature on the technology of growing } \\
\text { crops with sludge. } \\
\text { 2. Lack of special training. } \\
\text { 3. Lack of a system for special consultation and advice. } \\
\text { 4. Need for additional information, training, consulting and exchange of } \\
\text { experience of farmers. } \\
\text { 5. Reluctance to share positive experiences. } \\
\text { 6. High asymmetry between WTP and farmers, and with control bodies }\end{array}$ \\
\hline
\end{tabular}

Note: built on base of the interview with WTP managers and farmers

The requirements of the European Directive are also introduced in the national legislation in the Ordinance on the procedure and manner of utilization of sludges from wastewater treatment through their use in agriculture (adopted by [15]). It determines the order and the manner of utilization of the sludge from treatment plants and wastewater treatment facilities through their use in agriculture. And the requirements that sludge must meet in order to ensure that it does not have a detrimental effect on human health and the environment, including the soil; and the procedure for reporting the used sludge. According to the regulation, «sludge users» can only be sole traders and legal entities. The ordinance does not allow the utilization of sludge on: - meadows, pastures or areas sown with fodder crops, when used for grazing or the fodder is harvested in a period shorter than 45 days after the use of the sludge; 
- soils on which fruits and vegetables are grown, with the exception of fruit trees and vineyards;

- soils intended for the cultivation of fruit, vegetables and other crops which are in direct contact with the soil and are consumed in the raw state, for a period of 10 months before and during the harvest;

- coastal floodplains, riverbeds and protective dikes; - zone I and zone II of sanitary protection zones of water sources and facilities for drinking and domestic water supply and around water sources of mineral waters used for medical, prophylactic, drinking and hygienic needs;

- in agricultural land in protected areas.

The utilization of sludge in agriculture is allowed on the basis of a permit. For the issuance of a permit, sludge users provide to the Bulgarian Food Safety Agency (BFSA) information and results of analyzes of the soil from the places where the sludge will be used, of the soil characteristics: soil type, bulk density, soil particle size distribution, and total soil porosity. The sampling and their subsequent testing is performed by accredited laboratories according to certain indicators. Soil testing is mandatory before the initial use of sludge, and after their use - every 5 years. The permit contains: the quantities of sludge meeting the MDK for heavy metals in the sludge, expressed in tonnes of dry matter, which may be imported annually into the soil per unit area; the location and size of the landplots on which the sludge will be used. The permit is issued for a single application of a certain amount of sludge for a specific plot.

The bodies related to the implementation of an ordinance and control of its implementation are a key element of the institutional structure. The control over the application of the ordinance is assigned to the Minister of Agriculture, Food and Forestry, to the Minister of Environment and Water and to the Minister of Health in accordance with their competencies. In fact, these functions are performed by the specialized agencies of these ministries, whose functions are described in detail in the regulatory documents.

Regulatory requirements for the management of sewage sludge are also contained in other official documents, most of which are related to the legislation on waste and water management. It can be concluded that in Bulgaria there is a modern legislative and regulatory framework for safe use of sludge in agriculture, which is based on modern European standards. The ordinance regulates and restricts the use (permits for doses and plots) and users (sole traders and legal entities) of sludges from wastewater treatment in agriculture.

It is to be taken into account that the institutional requirements and restrictions, and the standards for quality and safety of food and feed, protection of the natural environment and biodiversity, animal welfare, etc. in the EU and Bulgaria are constantly evolving and «tightened». This modernization also affects the monitoring and control system and is closely linked to the support of farmers with CAP instruments (cross compliance, eco-payments, eco-contracts, overall «greening», etc.). For example, the newly adopted by the European Union in 2019 Green Deal sets ambitious goals in terms of reducing greenhouse gases, using mineral fertilizers and pesticides, and increasing the area with organic production by 2030 [16]. Discussions are still ongoing in the EU countries and in the Union's governing bodies, and procedures are being developed to achieve these goals through the CAP instruments, the Strategic Development Plans until 2030, and other policies and mechanisms. In this regard, there is considerable lack of precision and «institutional uncertainty» on many issues related to the achievement of European goals. And in particular how the reduction will be distributed among the individual EU member states, production sub-sectors, agricultural and agri-environmental regions and types of farmers, whether the total reduction will include and how the use of manure and sludge, etc. The degree of use of sludge in agriculture in the coming years will largely depend on the solution of all these issues.

Another factor is the possibility and the degree of implementation and control of the procedures, standards and restrictions for the use of sludge in agriculture by the competent state authorities. In the years of the country's membership in the EU, there are many examples of incomplete and «Bulgarian way» implementation of the common policies of the union. Moreover, there is no long-term and widespread experience in the use of sludge in agriculture in the country and almost all agents are outside or at the beginning of the «knowledge curve». The later leads to unintentional errors in the implementation and/or search for «effective» practical solutions outside the regulatory framework, etc. Finally, many of the eco-activities and eco-standards in agriculture are difficult to effectively control by enforcing authorities due to high cost or practical impossibility. This is related to the well-known «mass» non-compliance with certain official eco-standards and norms, etc.

Agents involved in the management of sludge ruse in agriculture are regulatory and controlling (state, regional, etc.) authorities, WTPs, sludge using farmers, other farmers and agents (landowners, traders, processors, etc.), population and business in the area, end users, interest groups, etc. An important component of the analysis of institutional factors is the interests and incentives of the participating agents and the nature of their relationship.

The state regulatory and controlling bodies are the main agent in the system. They apply the provisions of the legislator and the policies pursued by the government. One can only assume that (like other state structures) mistakes are likely to be made due to lack of experience in this «new» area, poor governance, and incompetence of employees. In addition, corruption is possible, as is the practice in all cases of licensing, control of certain practices and standards, etc. The same applies to some of the accredited laboratories, whose activity is not always in accordance with the regulations (imprecise tests, purchase and falsification of results, etc.).

In addition to the regulatory and controlling bodies, the main agents of the system are WTPs and sludge using farmers. The relations of WTPs and sludge utilization farms with the state authorities are of «unilateral» dependency. Applying for permits is voluntary, but permits are given, and this involves procedures, time, labor costs, payments for tests, etc. In addition to permits, other parameters of the process are determined (restricted) - technology of application, mandatory standards, time periods, etc. However, the control over the implementation of the regulations is divided between many structures, which complicates the coordination between them and creates difficulties for the other participants. At the same time, there is a situation of few players, and the agents «know» each other well, 
which should facilitate the relationship in the interest of «overall» efficiency. This situation often contributes to the easy development of «personal ties» and «coalitions» that are detrimental to the effective implementation of the legislation. A major problem identified by the present study is the slow issuance of new permits by public authorities.

The high asymmetry of the information between the interested agents (the state, WTP, farmers, consumers, etc.) provides a great opportunity and creates incentives for non-compliance (violation) of the requirements of the regulations, both by WTPs and by farmers using sludge. For example, it is practically possible that there are cases when incompletely treated sludge is provided to farmers by WTPs and imported into agricultural lands, that sludge per unit area is applied higher than the allowed norms. That sludge is also applied to unauthorized agricultural plots, and that sludge is applied in the not indicated manner (with simultaneous burying), etc. All this is associated with a number of risks and actual negative effects in terms of cleanliness of roads, soil, water and air, the health of farm workers, consumers of products, etc.

The contradictions and conflicts of the interested agents (and the individual, economic and social effects) in the process require the development of a special system for management and control of sludge utilization in general and in agriculture in particular. This is associated with additional costs for individual agents and society as a whole (taxpayers) - for maintaining government agencies, for studying and complying with regulations, for soil testing, for obtaining permits, for relationships with government institutions, etc.

The introduction of a system of permits and control is also associated with the development of «dependency relationships», as well as the possibility of unregulated payments (and corruption) for fast and/or illegal obtaining of permits, for reduced or inefficient control of the implementation of legal norms and restrictions. And as a result of insufficient or inefficient utilization of sludge in agriculture. The degree of actual non-compliance with regulatory constraints is difficult to assess, as the agents involved are not interested in sharing this type of information and it is impossible to accurately «measure» this type of effect from third parties (researchers, etc.).

The relationship between the WTP and the beneficiary farmers is contractual, based on one-year or multi-annual agreements. Like all contracts, the parties are free to specify the terms of the exchange and terminate their relationship in the absence of benefit. Moreover, in most cases the relations between the WTP and the utilizing farmers are of «bilateral» (symmetrical) dependency - capacity, location, time of supply, etc. It is determined by the fact that the agricultural utilization of sludge in the country is in the initial stages. And with a consistent strategy in this regard the assets of the WTP for treatment and the obtained «product» are in partial or complete high bilateral dependency with the assets (agricultural land with permits obtained) of the sludge using holdings. The degree of this dependency is determined by the amount of sludge for «agricultural» use, and the (limited) number of permits for sludge use in the plots of certain farmers. Long-term relationships between the same partners with symmetrical asset dependencies help to get to know each other well, develop trust, seek cooperation, limit opportunism, share information, and develop mechanisms for coordinating and resolving conflicts, and minimizing transaction costs. This further facilitates the relationship, reduces the associated costs, and increases the efficiency of sludge utilization in agriculture. In this regard, it is important to establish how the WTP selects the particular farmers with whom the sludge is experimented with or widely-utilized, especially when there is a «deficit» of valuable sludge resources in a given area.

Other interested parties (landowners, neighboring farms and businesses, the population in the area, interest groups, consumers, etc.) are also involved in a «relationship» with the WTP, sludge-using farmers and public authorities. However, individual agents do not have the «power» to change dominant practices due to the small size of the (negative) effect on them, the high individual costs and opportunities for «free riding» (one invests costs and everyone benefits if successful), the difficulty of common «collective actions» of agents with divergent interests, power positions and «dependency» by large (sludge-using) producers in the region, etc. Only when the effect is highly negative and direct (for example, a strong odor when delivering and spreading sludge) the strong collective actions of the population in the area are possible and often lead to the cessation of sludge supply for short periods of time.

The efficiency and incentives for the application of sludge instead of mineral fertilizers will depend strongly (in direct proportion) on the price dynamics of mineral fertilizers of different types (mainly $\mathrm{N}$ and $\mathrm{P}$, whose substitute is sludge). In addition, interest in the use of sludge may increase with mandatory or voluntary (for getting public subsidies) restrictions on the use of mineral fertilizers in certain areas, sub-sectors or types of farms in the EU.

There is a psychological barrier, due to the «special nature» of this fertilizer, both in the farmers themselves and in the landowners and the residents of the area, for the negative effects of the use of sludge in agricultural land. These informal «rules of the game» and how they affect each of the stakeholders are to be analyzed. In other EU countries, for example, in areas with highly developed livestock and mass application of manure, there is a higher tolerance for the application of sludge in agriculture, both by farmers and the general population.

The market and buyers are also not yet «open» to the widespread use of sludge in agriculture. Many wholesale buyers and end users question the safety of products produced with sludge use. This is often associated with lower sales prices of farm products and high marketing costs. Last but not least, farmers and other stakeholders themselves are concerned about the long-term effects of sludge use on the environment - cleanliness and quality of soils and waters, trampling of agricultural land, protection of natural biodiversity, maintaining the ecological sustainability of farms, etc.

The specific institutional structure and the participating agents, in turn, can and do participate in the modernization of national and European policies. However, the repercussions of these elements are severely limited because the «political process» is slow, with different priorities, and not always in the interests of overall efficiency. The same applies to the direct impact of these agents on the development of product and resource markets (fertilizers, agricultural land, etc.) and the natural environment due to lack of complete information, complexity, high uncertainty, and the need for expensive and long-term collective actions on a huge scale and scope. 
The main agents involved in the management of the process of sludge use in agriculture are WTPs and farmers. In principle, all WTPs should have an interest and developed strategies for effective management, and at the present stage for effective utilization of sludge. It can be assumed that to achieve economies of scale and scale (for both WTPs and farmers), certain optimal amounts of sludge produced will be needed to invest in modern equipment for effective treatment, as well as certain minimum sizes of land plots and farms in order to make efficient transportation and import of fertilizers with specialized equipment.

The individual WTPs in the country to varying degrees implement effective strategies for sludge utilization in general, and in agriculture in particular. For example, the Management of «Sofiyska Voda» AD has a clear vision and takes comprehensive measures for the utilization of sludge in agriculture. The quantities of sludge are significant, which makes technologically modern and economically advantageous treatment possible. For years, good relations have been maintained with large farmers in areas where sludge is provided free of charge. The company's experts are also involved in acquiring permits for sludge utilization for the respective land plots in the area. In addition, the company provides transportation and spreading of sludge. In this way, the company creates favorable conditions for the utilization of sludge produced in WTP and strong incentives for farmers to use sludge on farms. In order to minimize the transaction and other costs for relations with state bodies and farmers, it works with a limited number of large agricultural producers in the region.

This company also works closely with research institutes to explore ways to increase the efficiency of the sludge process. Media appearances are also made to inform the public and promote the utilization of sludge among the agricultural producers. The company's long-term strategy is to commercialize the «produced» sludge and sell it on the fertilizer market to offset the significant costs of treatment and storage. Therefore, the experience so far is a kind of experimentation and demonstration of the socio-economic efficiency of agricultural sludge use in the long-term profit strategy for the company. However, it is not known how the «increase in the price» of sludge will change the incentives of farmers for their economic utilization. In the absence of additional incentives (e. g. public subsidies, personal conviction, etc.), any increase in costs (prices) for farms will lead to a reduction in economic effects and incentives for agricultural use of sludge.

After the study of WTPs in the region of Burgas, it was found that the utilization of sludge is still a challenge for most of them. In some places, a much broader information campaign is needed among farmers. At this stage, there are reservations of some managers of treatment plants and farmers to use the disposed sludge in agriculture, mainly related to the proximity of the area to the sea-coast and developed tourism. Some WTPs do not yet have complete equipment for effective sludge treatment, while others do not have sufficient quantities for possible treatment and extensive use. In the past, a large agricultural producer in the region applied sewage sludge (102 ha with coriander, rapeseed, etc.), but gave up due to the complicated monitoring for soil and sludge testing. Currently, there is also interest from a farmer, who is pay for drilling and testing soil samples, transporting the sludge, and spraying and mixing the sludge with the soil.
Conducted research found out that for different WTPs there is a different comparative efficiency of agricultural sludge utilization depending:

- on the volume of sludge;

- available landfills;

- existing treatment facilities and equipment;

- the level of costs for effective treatment;

- state and public pressure and tolerance;

- the possibilities for alternative use, etc.

With relatively low economic efficiency for agricultural use, WTPs do not have strong incentives and strategies for the development of this process, and state intervention will be required - support, financing, information, etc.

Farmers, on the other hand, have an economic interest in using innovations like sludge to fertilize the soil in order to increase production efficiency. The use of sludge can also have positive agronomic, production, ecological and other effects (improvement of the structure, aeration and moisture retention of the soil, reduction of erosion, faster germination and vegetation development of the plant, higher quality of production, etc.), which further stimulate economic use. Therefore, the attitudes and capabilities of different types of farmers regarding the application of the innovation «fertilizer sludge» are to be studied.

In addition, it can be assumed that a certain minimum size of land plots and farms is necessary not only to achieve economies of scale and scale in the transportation and application of fertilizers with specialized equipment, but also to justify the additional costs of training, information, experimenting, taking on possible losses, relationships with organizations, etc. Some specialization is also likely to be required for the efficient use of sludge to produce one or two of the permitted crops.

3.2. Personal, educational and informational factors. A very important factor for the efficient utilization of sludge in agriculture are the personal characteristics of farm managers (Table 2). All of the long-term sludge using farmers are good entrepreneurs and managers, with a high innovative spirit and qualification, and a tendency to seek solutions, experiment and take risks to increase profits. They have «discovered» great economic potential in the use of sludge as fertilizers, assume a certain production and financial risk and losses, invest in new knowledge, adapt technology and organization of production, develop relations with WTP, etc. for its realization. Like any innovation, «fertilizer sludge utilization» is associated with a certain economic risk and the need for non-standard management decisions, and entrepreneurial (risk-taking) farmers are not many in this regard.

Another important factor for increasing the utilization of sludge in agriculture is the availability of comprehensive, up-to-date and reliable information on the opportunities, ways, conditions, effects, challenges and risks associated with sludge utilization in agriculture. Adequate regulatory, scientific, experimental and practical information is important not only for farmers, but also for all other participants in this process - government agencies and employees, WTPs, farmers, stakeholders, end users and the general public.

Conducted research found that such information in Bulgarian (only accessible to most agents) and the specific conditions of the country and its individual regions is very scarce and often contradictory. Very few publications are widely available, mostly in academic publications 
little read by farmers, businesses, the general public, etc., which are mainly based on experimental and laboratory experiments, most often presented in a foreign language. For example, a Google search can find a small number of publications in recent years by a limited number of authors. Occasional information may appear in the media, mainly about regulatory documents or publications induced by interested parties.

Moreover, there are virtually no comprehensive assessments of the actual socio-economic and complementary effects of sludge use on farms of different types, specializations and locations. In addition, the results of published scientific, experimental and laboratory tests and trials are based on ideal conditions (optimal farming techniques, correct fertilization rates, good management, etc.), which differs significantly from the actual practice of farms. For example, experiments are made with perfectly treated sludge, while in practice the sludge is often delivered and imported in a different state from the regulatory requirements not treated or partially treated, with high humidity, etc.

The study found that many farmers are partially aware of the possibility of sludge utilization, but there is a strong lack of information on the necessary conditions, potential effects, risks, costs, etc. The lack of adequate information on these issues also has a negative impact on the attitudes of the population, producers in the area, and intermediates and end buyers of the product. The information deficit is most often «filled» with false information about the possible effects of agricultural use, and resistance from both farmers and other stakeholders.

In some scientific institutes of Agricultural Academy and other institutions there has been a long-term research on the chemical, biological and agronomic effects of the use of sludge in agriculture. However, the volume and nature of these studies do not correspond to the modern needs of farmers and society. There are no interdisciplinary studies on this important issue. There is a lack of independent tests and demonstrations, and promotion of practical utilization of sludge in experimental or economic conditions, and specific guidelines for optimal application in farms with different specialization, size, ecological and geographical location, etc.

The utilization of sludge in agriculture is a complex and dynamic process that requires long-term specialized training and consultation of farmers. Conducted research found that there is no specialized training and consulting in the country dedicated to the utilization of sludge in agriculture. For example, in the Agrarian and related universities, Agricultural Academy and National Agicultural Adviroy Service there are no highly qualified experts for long-term training and consulting of interested farmers. Some farmers also state that they «do not trust the local institutes» and therefore do not seek their services. All this makes it very difficult to make an effective transition to sludge utilization in agriculture.

Some farmers who use sludge in agriculture conduct their own experiments, find their own solutions and/or seek and find the necessary information and training, including from abroad. Some of them consult each other, exchanging experience and useful information, or seek external advice from private consultants, WTP experts, researchers, etc. At the same time, depending on personal characteristics (managerial experience, qualifications, innovation, etc.), self-training or «learning by doing experi- ence» requires different time and gives different results for individual farmers. And in some cases can lead to incorrect or inefficient use of sludge, and not infrequently to the cessation of sludge use on farms.

However, conducted study found that most sludge using farmers are reluctant to share their experiences for a variety of reasons - lack of time, reluctance to publicize, firm secrets about yields and profits from competitors, etc. An important reason for this is that they do not want to increase the interest of new farmers in the use of sludge, as this will increase demand in the area, increase the «price» and reduce «profitable» access to the limited resource «sludge». This further slows down the spread of this new practice in the country.

\subsection{Production, socio-economic and environmental factors.}

The main incentives for the use of sludge by farmers are the production and economic benefits (Table 3 ). Conducted study found that all users of sludge are large producers who have a strong interest in minimizing the cost of fertilization and have the capacity to bear the additional costs of «external» relations with WTPs and government agencies, experimentation, training, reorganization of the production process and management, risk-taking and possible losses, etc.

All sludge users report that the effect of replacing mineral fertilizers with sludge occurs over a long period of time. In the first years after the application of sludge, the yield usually decreases, and subsequently recovers and even increases without the need for annual fertilization with mineral fertilizers. One-time fertilization with sludge allows to replace the mineral fertilization for the entire regulatory period of 5 years, before re-application of sludge on the same plots. Therefore, the one-off costs associated with obtaining permits, supplying and depositing sludge is to be compared with the current savings from the reduced (removed) mineral fertilization during the period of effect realization.

«Sofiyska Voda» AD provides (personnel, covers costs, etc.) for obtaining permits for sludge utilization, and provides free of charge sludge and transportation to the farm, additionally providing a machine and operator for sludge covering (only the fuel is paid by the using farmer). The costs for mineral fertilizers represent the main part of the production costs of the farms in the region - about 35-40\%. Therefore, replacing mineral fertilizers with sludge fertilizer can lead to significant economies in large scale utilization.

It is reported that the effect is obtained in all types of soils, except sand, and the best results are obtained with corn in the same arrays $-6000-7000 \mathrm{~kg} / \mathrm{ha}$ with irrigation. Without irrigation, there is no difference in yield, but only different costs of fertilization with mineral fertilizers and sludge, and yields strongly depend on an «external» factor - the amount of rain during the year. In cereals (wheat and barley) the effect is at the earliest in the third year, as the first and second year burn.

In the utilization of sludge, significant savings are additionally made to the need for deep plowing, for the application of fertilizers, for irrigation (for needy crops such as corn), for the payment of interest on loans for the purchase of mineral fertilizers, to save on and more productive use of own working capital, available equipment and manpower, etc. These supplementary effects are of great importance since the financial condition of most farms in the country is not good. 
Production, socio-economic and environmental factors for sludge utilization in Bulgarian agriculture

\begin{tabular}{|c|c|c|}
\hline Туре & Positive & Negative \\
\hline $\begin{array}{l}\text { Agronomic, } \\
\text { technological } \\
\text { and pro- } \\
\text { duction }\end{array}$ & $\begin{array}{l}\text { 1. Improve soil structure. } \\
\text { 2. Improve aeration and soil moisture retention. } \\
\text { 3. Faster germination and vegetative development of the plant. } \\
\text { 4. No need for deep plowing, mineral fertilization and irrigation. } \\
\text { 5. Better compensation of } \mathrm{N} \text { and P uptakes and soil enrichment. } \\
\text { 6. Increase land productivity and yield. } \\
\text { 7. Improve the quality of produce. } \\
\text { 8. Water retention. } \\
\text { 9. Easy to apply to large farms specializing in field crops. } \\
\text { 10. More efficient use of land, material, labor and financial resources }\end{array}$ & $\begin{array}{l}\text { 1. Technologically limited period of time for transportation and import of } \\
\text { large amounts of sludge on many farms. } \\
\text { 2. Compaction of the soil when applying the sludge. } \\
\text { 3. Needs to monitor for heavy metals and soil acidity. } \\
\text { 4. Different results depending on the characteristics of the soil, cultivated } \\
\text { crops and varieties, and the amount of rain or irrigation. } \\
\text { 5. Difficulties for use by small and medium farms. } \\
\text { 6. Impossibility for use in all crops (vegetables, etc.). } \\
\text { 7. Diverse results depending on production conditions and crops. } \\
\text { 8. Potential sludge shortage for all interested farmers in the area }\end{array}$ \\
\hline Social & $\begin{array}{l}\text { 1. Increasing amount of sludge produced in the region. } \\
\text { 2. Lack of alternative use of sludge and lands for disposal. } \\
\text { 3. Public and international (EU) pressure. } \\
\text { 4. Increase in the income of farmers. } \\
\text { 5. Increase of sustainability of agricultural holdings. } \\
\text { 6. Reduce the amount of waste and the total cost of waste stor- } \\
\text { age and disposal. } \\
\text { 7. Improve competitiveness. } \\
\text { 8. Easy to apply to large and remote from settlements and other } \\
\text { businesses farms. } \\
\text { 9. Quick burial of the sludge to eliminate the unpleasant odor }\end{array}$ & $\begin{array}{l}\text { 1. Conflict between economic and social effects. } \\
\text { 2. Deteriorate working conditions during periods of sludge application. } \\
\text { 3. Decrease comfort of the population during periods of sludge application. } \\
\text { 4. Unfavorable wind direction during delivery, spreading and plowing of sludge. } \\
\text { 5. Public dissatisfaction with the appearance of a specific odor. } \\
\text { 6. Landowners reluctance to provide land for rent. } \\
\text { 7. Need for public regulation and control. } \\
\text { 8. Conflicts with other farmers and stakeholders. } \\
\text { 9. Reluctance of beneficiary farmers to share their positive experiences for } \\
\text { various reasons. } \\
\text { 10. Unacceptable for use in fruits, vegetables, etc. crops for direct human } \\
\text { consumption. } \\
\text { 11. New EU goals for significant reduction of greenhouse gases, use of } \\
\text { fertilizers and increase of organic farming. } \\
\text { 12. Needs for long-term social dialogue and costs to promote agricultural use }\end{array}$ \\
\hline Economic & $\begin{array}{l}\text { 1. The growth of mineral fertilizer prices. } \\
\text { 2. Minimize or remove the cost of mineral fertilizers for a long } \\
\text { period of time. } \\
\text { 3. Increase the average yield. } \\
\text { 4. Larger cobs, ears, grains and leaves (for silage, straw). } \\
\text { 5. Negotiating a better selling price for better quality grain. } \\
\text { 6. Bigger profit. } \\
\text { 7. Savings on material and labor costs. } \\
\text { 8. Increase sustainability. } \\
\text { 9. Improve competitiveness. } \\
\text { 10. Reduce the needs for working capital and/or external lending } \\
\text { and payment of interest and liabilities. } \\
\text { 11. Inclusion of farms in the circular economy. } \\
\text { 12. Better use of farm resources }\end{array}$ & $\begin{array}{l}\text { 1. Increased costs for negotiation and relations with WTP. } \\
\text { 2. Increased costs for study and implementation of regulations. } \\
\text { 3. Costs of time and funds for obtaining permits and relations with state bodies. } \\
\text { 4. Increased costs of information, exchange of experience, training and } \\
\text { management related to the use of sludge. } \\
\text { 5. Increased costs for experimentation and for studying the effects in the } \\
\text { conditions of each farm. } \\
\text { 6. Additional costs for laboratory tests of soil, produce, etc. } \\
\text { 7. Increased costs for relationships with landowners, buyers, local govern- } \\
\text { ment, and the public. } \\
\text { 8. Additional costs for transportation, covering and plowing of sludge. } \\
\text { 9. Need to pay for sludge (in the near future). } \\
\text { 10. Increased labor compensation costs. } \\
\text { 11. Need for a certain concentration and specialization of production in the farm }\end{array}$ \\
\hline Ecological & $\begin{array}{l}\text { 1. Maintaining and improving the fertility and quality of agri- } \\
\text { cultural land. } \\
\text { 2. Reducing soil erosion. } \\
\text { 3. Increased water storage on farms. } \\
\text { 4. Application of sludge in the summer to reduce soil compaction. } \\
\text { 5. Increased ecological sustainability of agriculture. } \\
\text { 6. Improved and more efficient waste management. } \\
\text { 7. Reduction of greenhouse gases in the production and supply } \\
\text { of mineral fertilizers. } \\
\text { 8. Restrictions on use in protected areas }\end{array}$ & $\begin{array}{l}\text { 1. Greenhouse gases emission in sludge treatment and use. } \\
\text { 2. Air and road pollution. } \\
\text { 3. Risks to natural biodiversity. } \\
\text { 4. Groundwater pollution. } \\
\text { 5. Pollution with heavy metals. } \\
\text { 6. Soil trampling. } \\
\text { 7. Need for careful use and precise control in coastal, riparian, lakeside } \\
\text { and water supply areas. } \\
\text { 8. Uncertainty related to long-term effects. } \\
\text { 9. Pre-existing before sludge use contamination of soil and waters }\end{array}$ \\
\hline
\end{tabular}

Note: built on base of the interview with WTP managers and farmers

In addition to fertilizer savings, the application of sludge also leads to an increase in the total yield during the period, and depending on the crop and the amount of sludge, this increase can be 2 or more times. It should be borne in mind that in the first $1-3$ years after the introduction of sludge there is a sharp decline in average yields, and loss of profitability of the affected plots of farms. Given the massive underuse of mineral fertilizers in the country, it can be assumed that the total effect of sludge imports is significant, as simultaneously with increasing yields it effectively recover the $\mathrm{N}, \mathrm{P}$, and $\mathrm{K}$ uptakes and maintain (and improve) soil fertility. Besides, the use of sludge is associated with additional environmental benefits such as improving the structure and quality of soils, reducing soil erosion and more.
The study found that the effect of fertilization with sludge on yield depends on the crop and varieties used, crop rotation, type and stocking of soils with N, P, K and other elements, etc. Yield also depends on the varieties grown, with many farmers preferring foreign varieties because of significantly higher yields other things being equal. A critical factor is the amount of rain, on farms that do not use crop irrigation due to the needs of high investment, the high price of water for irrigation, lack of permits for groundwater extraction, etc. It should be borne in mind that there are cases in which the legally permitted norms of sludge per unit area are increased (up to 3 times) and/or sludge is imported on more than the designated areas in order to maximize the yield.

Farmers also report increasing cob size and grades, improving product quality, increasing green mass (for silage 
and/or hay), which increases sales prices, increases profits and/or facilitates product marketing. These effects are especially important, given the high costs and difficulties associated with the sale of products on many Bulgarian farms.

The utilization of sludge in farms is also associated with maintaining soil fertility, as due to high prices mineral fertilizers are not used sufficiently (optimally). This is also an important indicator of the good environmental sustainability of the farmer. At the same time, however, some farms emphasize that «if possible, they will only apply mineral fertilizers, as they are safer».

The study also found that the application of sludge helps to improve (even double) the retention of moisture in the soil, and can achieve significant additional savings from irrigation and increase yields, in conditions of constant decreases in rainfall in recent years and high costs or lack of technical possibility for irrigation. At the same time, during the delivery and spreading of the sludge, the soil is compacted, its structure is compacted, and the aeration is disturbed, hindering the development of the plants and reducing the yield in the first years. To reduce compaction, the sludge is applied in the summer, after harvest, when it is driest.

The import of sludge requires not only a change in agricultural technology, but also a new better organization and management of production. For example, there is a relatively short technological period after the harvest (JulyAugust) for the delivery, spreading and plowing of the sludge. Upon delivery and especially with delayed plowing, an unpleasant odor spreads, which causes dissatisfaction from neighboring farms and businesses and even residents of nearby settlements. In case of strong odors, it is even necessary to interrupt the process in order to «calm the dissatisfaction of the population», which further shortens the practically possible period for the introduction of sludge.

Along with the economic benefits for the farms, the utilization of sludge is also associated with additional costs for relations with WTPs, controlling bodies, soil sampling, etc. For example, contracts between WTPs and farmers are not complete, require additional costs to coordinate and resolve potential conflicts, and so on. Non-exhaustive contracts also allow for unilateral «breach» of the agreement by the WTP at the expense of farmers - untimely delivery, delivery of sludge in various quantities and quality, temporary suspension of supplies to calm public discontent, etc. In addition, WTPs usually apply standard contracts that are not adapted to the specific conditions of a particular farm. This further increases the costs in the process of sludge utilization for adaptation, coordination between partners, contestation, etc.

On the other hand, (profit-oriented) WTPs also seek to minimize their costs for agricultural sludge utilization and prefer large farms near sludge landfills as contractors cost savings for contracting and relationships, for obtaining permits (no fees are charged), on the paperworks and long procedures, soil samples, for transportation of sludge, etc. In all cases where the transaction costs for farmers and/or WTPs are very high, agricultural sludge utilization is reduced or completely blocked, regardless of the potential (production, economic, etc.) benefits for both parties.

The widely used practice of one-year land lease agreements of large farms with numerous landowners also creates an additional risk of damage (loss of one-time long-term investments related to the supply and use of sludge) in case of refusal of the landlords to renew the contract on landplots with sludge or permits, during the new business season (alternative use, sale, provision to another tenant, reluctance to deposit sludge, etc.).

Many of the above costs cannot be measured in monetary terms, but it is obvious that the one-off investment in the supply and import of sludge as fertilizers is recouped many times over from the additional profit received. Moreover, this type of investment has a much higher return (absolute and comparative efficiency) than other (traditional) capital investments in agriculture.

Most sludge using farms do this for a long period of time, in some cases up to two decades. This shows that good relations have been developed between farmers and WTPs, a good reputation and trust has been built between the partners, and mechanisms for coordination and conflict resolution, and for minimizing transaction costs. In addition, the long period of use of sludge from a holding is an important indicator of efficiency, as with insufficient additional benefits (effects) and high associated costs, farms quickly stop this practice («low exit costs»).

The study found that the revenues of sludge recovery farms are between 211-302 USD per ha after deducting rent, depreciation and wages. The investment is cost-effective, and if allowed, many farmers would fertilize all areas with sludge. The use of sludge increases income, financial opportunities, competitiveness and economic sustainability of the enterprises. This also leads to higher social sustainability, as it provides employment in the region, and increases the viability of agriculture.

The studies also identified the main factors that increase or decrease the interest in the utilization of sludge by farmers who do not currently use sludge [17]. Most of them are «generally» aware of the possibilities for using WTP sludge as fertilizer and its potential benefits. They receive this information informally either from the media, or from other producers, or from scientists, or from various publications in the press, or from direct monitoring of sludge farms. At the same time, however, very few nonusing farmers have in-depth knowledge of the multifaceted socio-economic and environmental effects of agricultural sludge utilization.

A major factor restricting experimentation with or transition to sludge utilization is the release of the specific odor and negative public opinion. The study found that the main reason for this is that sludge is used only by large farms and for a short period of time large quantities are delivered and inputted in certain landplots or areas. In addition, the regulations for maximum permissible sludge moisture, maximum quantities per unit area, obligation to plow on the same day of delivery and laying, etc. are not always observed. To reduce these effects, in case of strong odors, many farmers stop introducing sludge for 1-2 days, and/or comply with the direction of the wind not to be towards the settlements. At the same time, if the sludge is provided to several smaller holdings and distributed to larger areas, and if the established doses and regulations are observed, the odor will not be a significant problem.

Concerns about the possible negative effects on soil quality, the health of workers, the population and animals, guests (tourists, etc.) in the area, etc. are also often mentioned. Many land-leasing holdings and cooperative farms worry that landowners and cooperative members will block such a decision by terminating leases or voting in 
the general meeting. At the same time, producers whose lands are in remote areas of the settlements point out that the smell is not a significant limiting factor. In addition, in order to reduce the unpleasant odor and dissatisfaction of the population, farmers practice rapid burial after the delivery and spreading of sludge in agricultural plots.

Many farmers also believe that if the sludge is not provided free of charge but sold as a fertilizer product, this would further limit its agricultural use. There is no market for such a product in the country, and the supply will be monopolized (a single supplier) in the respective WTPs regions. At the same time, this product is not very specific to the farm, as there are many alternatives among other (mineral, manure, etc.) fertilizers. Moreover, competition with and from companies supplying mineral fertilizers is high, with mineral fertilizers usually sold in a «package» with additional services (lending, delayed payment, consulting, seed provision, etc.). In addition, it is found that some non-sludge farmers in the area are convinced that farms that use sludge (defined as «waste») receive payment for it from the WTP. Therefore, a strong development of the «sludge market» and trade in sludge at high prices cannot be expected in the coming years. Increased costs for efficient sludge utilization in general and in agriculture in particular will continue to be mainly covered by WTPs (and water users respectively) and/or public programs (respectively by European, national or local taxpayers).

\section{Conclusion}

In the course of the research, we have managed to identify multiple factors affecting sludge utilization as a fertilizer in Bulgarian farms. This study is only the first stage of a larger study to establish the diverse effects and factors of sludge utilization in Bulgarian agriculture. The factors and effects of the circular economy are strictly specific to the conditions of each economic organization, the individual sub-sectors of agriculture, the different ecosystems and regions in which the usage takes place. Therefore, efforts will be focused on the next stage of development to clarify the farm, sectoral and regional specificities.

Given their relevance, research of this kind should be continued and deepened and should be based on more representative information from all participating agents and stakeholders. In addition to identifying the factors and their direction (positive, negative), the degree of their significance should be assessed by an interdisciplinary panel of experts in the field. On this basis, specific recommendations can be prepared to improve the utilization of sludge in agriculture to improve the policies, public support and institutional arrangements, and management strategies of WTPs and potential and sludge-using farmers.

\section{Acknowledgments}

This study has been financially supported by the $\mathrm{Na}$ tional Science Fund of Bulgaria. The authors are grateful to all participants for their cooperation and provided information.

\section{References}

1. Roundtable discussion on sludge use (2021). EU. Available at: https://ec.europa.eu/environment/archives/waste/sludge/pdf/ workshoppart5.pdf
2. Wate water treatment - sludge management (2021). Eur Eau. Available at: https://www.eureau.org/resources/briefing-notes/5629briefing-note-on-sludge-management/file

3. Doklad ot izplnitelna agentsiia po okolna sreda otnosno chl. 16 , al. 2 ot naredba za reda i nachina za opolzotvoriavane na utaiki ot prechistvaneto na otpadchni vodi chrez upotrebata im v zemedelieto (2019). IAOS. Sofiia.

4. Natsionalen strategicheski plan za upravlenie na utaiki ot prechistvatelnite stantsii za otpadchni vodi v Blgariia za perioda 2014-2020 g. (2014). NSPUU. Available at: https://www.moew. government.bg/static/media/ups/tiny/file/Waste/sewage_sludge/ Sludge_project_last/NSPSM_BG.pdf

5. Marinova, S. (2008). Utaiki ot prechistvatelni stantsii za otpadchni vodi i pravila za tiakhnoto opolzotvoriavane. Sofiia, 126

6. Usman, K., Khan, S., Ghulam, S., Khan, M. U., Khan, N., Khan, M. A., Khalil, S. K. (2012). Sewage Sludge: An Important Biological Resource for Sustainable Agriculture and Its Environmental Implications. American Journal of Plant Sciences, 3 (12), 1708-1721. doi: http://doi.org/10.4236/ajps.2012.312209

7. Hudcová, H., Vymazal, J., Rozkošný, M. (2019). Present restrictions of sewage sludge application in agriculture within the European Union. Soil and Water Research, 14 (2), 104-120. doi: http://doi.org/10.17221/36/2018-swr

8. Bachev, H., Ivanov, B., Mitova, D., Boevski, I., Marinov, P., Sarov, A. et. al. (2021). Mekhanizmi i formi na upravlenie na agroekosistemnite uslugi v Blgariia. Sofiia, 140. Available at: https://www. academia.edu/45656344/МЕХАНИЗМИ И ФОРМИ НА УПРАВЛЕНИЕ_НА_АГРОЕКОСИСТЕМНИИТЕ_УСЛУГИ В_БЬЛГАРИЯ

9. Bărbu, C. Aziri, B., Bachev, H., Diófási, O., Gupta, S., Ha, H. et. al. (2012). Management and Environmental Protection. ASERS Publishing. Available at: https://books.aserspublishing.eu/ eoconomica/catalog/book/4

10. Sewage sludge produced during the COVID-19 epidemic can only be applied to fields after disinfection (2020). ANSES. Available at: https://www.anses.fr/en/content/sewage-sludge-producedduring-covid-19-epidemic-can-only-be-applied-fields-after

11. Ivanov, B., Bachev, H. (2021). Convergent analysis of waste water practices among EU countries. Bulgarian Journal of Agricultural Science, 27 (2), 289-296.

12. Ivanov, B., Marinova, S., Bachev, H., Georgieva, V. (2020). Ikonomicheski i ekologichni efekti ot izpolzvane na utaikite v zemedelieto. Ekologichno inzhenerstvo i opazvane na okolnata sreda, 3, 44-53.

13. Siarov, A. (2020). Sotsialno-ikonomicheski, ekologichni i upravlencheski aspekti pri opolzotvoriavaneto na utaiki v zemedelieto, polucheni pri prechistvane na otpadchni vodi. Ikonomika $i$ upravlenie na selskoto stopanstvo, 1, 58-69.

14. Direktiva 86/278/EIO - Direktiva 86/278/EIO za opazvane na okolnata sreda $i v$ chastnost na pochvite, $v$ sluchaite na upotreba na utaiki ot otpadchni vodi v zemedelieto (1986). Available at: https://eur-lex. europa.eu/legal-content/BG/ALL/?uri=CELEX\%3A31986L0278

15. Naredba za reda $i$ nachina za opolzotvoriavane na utaiki ot prechistvaneto na otpadchni vodi chrez upotrebata im v zemedelieto (2016). Prieta s PMS No. 201. 04.08.2016 g. Available at: http://eea.government.bg/bg/nsmos/waste/naredba-utayki

16. The European Green Deal (2020). Communication from the commission to the european parliament, the european council, the council, the european economic and social committee and the committee of the regions. European Commission. Available at: https://eur-lex.europa. eu/legal-content/EN/TXT/?uri=CELEX\%3A52020DC0066

17. Vzmozhnosti ot opolzotvoriavaneto na utaiki, polucheni pri prechistvane na otpadchni vodi $i$ efekt za ustoichivo zemedelie, otchet na nauchno-prilozhen proekt (2021). IAI. Available at: https://mpra.ub.uni-muenchen.de/109606/

$\triangle$ Hrabrin Bachev, Professor, Department of the Economics of Farms and Agrarian Organizations, Institute of Agricultural Economics, Sofia, Bulgaria, e-mail: hbachev@yahoo.com, ORCID: https:// orcid.org/0000-0003-0555-7468

Bozhidar Ivanov, Associate Professor, Department of the Economics and Managmnet of Agriculture, Food and Agricultural Policy, Institute of Agricultural Economics, Sofia, Bulgaria, ORCID: https:// orcid.org/0000-0001-6305-9075

$\triangle$ Corresponding author 